\title{
Brexit i rewolucja populizmu w Europie.
}

\author{
Z Benem Stanleyem rozmawia Marek A. Cichocki*
}

\begin{abstract}
Zacznijmy naszą rozmowę od brexitu. Niedawno podjęto decyzję o odroczeniu wyjścia Wielkiej Brytanii z Unii Europejskiej na koniec października. Jaka jest Pana ocena obecnej sytuacji? Czy w tym wypadku odbędą się tam wybory do Parlamentu Europejskiego? Czy jesteśmy bliżej, czy może dalej od rozwiązania obecnego problemu?
\end{abstract}

Uważam, że jesteśmy coraz bliżej rozwiązania aktualnej patowej sytuacji. Zwłaszcza teraz, gdy znaleźliśmy się tak blisko wyjścia Wielkiej Brytanii z Unii Europejskiej bez umowy, ludzie zrozumieli wreszcie, że Unia nie blefowała. Zjednoczone Królestwo było do tej pory przekonane, że to Bruksela ustąpi w negocjacjach. Myślano, że Brytyjczycy podbiją stawkę i pozostając $w$ terminologii karcianej, UE zamruga jako pierwsza. Teraz zdano sobie sprawę, że tak się nie stanie. Unia stwierdziła, że brexit jej zaszkodzi, ale w o wiele większym stopniu zaszkodzi Wielkiej Brytanii. Zrozumienie tego zajęło Zjednoczonemu Królestwu za dużo czasu. Obecnie, gdy mamy więcej czasu na porozumienie się w sprawie wyjścia, łatwiej będzie nam sprawnie rozwiązać kryzys brexitowy niż kilka miesięcy temu, gdy nie było nawet wiadomo, czy premier Theresa May będzie chciała przedłożyć swoją umowę pod obrady parlamentu. Obecnie widzimy więc spory progres. W ciągu ostatnich kilku tygodni parlament stale przybliżał się do osiągnięcia porozumienia. Szok spowodowany zbliżającą się perspektywą wyjścia bez umowy przekonał wielu członków Izby Gmin, że należy zachować się poważnie, bo nie możemy liczyć, że zmusimy UE do podjęcia korzystnych dla nas decyzji. W tym sensie jesteśmy bliżej ostatecznego rozstrzygnięcia, nawet biorąc pod uwagę fakt odroczenia wyjścia z UE do końca października.

\footnotetext{
* Ben Stanley jest brytyjskim politologiem badającym współczesne ruchy populistyczne w Europie. Pracuje na stanowisku adiunkta w Uniwersytecie SWPS. Rozmowa przeprowadzona została w kwietniu 2019 r.
} 
Czy ta zmiana polega Pana zdaniem na tym, że bliżej dziś do uformowania się w brytyjskim parlamencie większości za jakimś konkretnym rozwiązaniem? Czy zaryzykowałby Pan stwierdzenie, jakie ono będzie?

Matematyka jest w tym wypadku skomplikowana. Wszystko zależy od tego, czy premier zdecyduje się na przedterminowe wybory, w nadziei że uda jej się zdobyć większość parlamentarną, aby nie zależeć od Demokratycznej Partii Unionistycznej, która jest dla Theresy May tak samo dużym problemem jak posłowie Partii Konserwatywnej optujący za twardym brexitem. Niektórzy zaczynają sobie wyobrażać możliwość porozumienia się co do umowy, zwłaszcza przy udziale opozycji. Ale w jakiej formie? W jakim stopniu premier może zależeć od opozycji? Jest za wcześnie, by wyrokować, a negocjacje trwają. Możemy rozważać różne opcje, ale musimy najpierw zobaczyć wyniki tych rokowań, żeby wiedzieć, jakiego kompromisu chce Partia Pracy.

Poruszamy się w kierunku, który daje większe szanse na stworzenie większości na rzecz jakiegoś porozumienia, tylko tak naprawdę nie wiemy, jakiego. Czy będzie to wymagało również zmiany podejścia do negocjacji ze strony Brukseli? Na razie mamy stanowisko, że porozumienie już jest i że Unia nie przewiduje od niego odstępstw.

Myślę, że jakaś forma ponownych negocjacji może być rozważana, jeżeli Partia Konserwatywna i Partia Pracy będą zmierzały do łagodniejszego brexitu. Realna wydaje mi się sytuacja, w której UE powie, że co prawda nie jest to umowa wynegocjowana wcześniej, ale nie wymaga wycofywania się z poprzednich ustaleń. To nie jest problem. Jeśli przygotujemy łagodniejszą umowę w sprawie brexitu, będzie to bardziej przemawiać do UE i da szansę na otwarcie renegocjacji poszczególnych aspektów porozumienia. Unia nie będzie natomiast popierać przejścia do bardziej twardego brexitu, czyli wyjścia bez umowy.

\section{A wyklucza Pan kolejne referendum w sprawie brexitu?}

$\mathrm{Z}$ politycznego punktu widzenia nie jest to gra warta świeczki - ani dla Theresy May, ani dla Jeremy'ego Corbyna. Co prawda wśród laburzystów pojawiają się głosy, że warto by przeprowadzić drugie głosowanie, jeżeli miałoby się to okazać jedyną drogą wyjścia z kryzysu, ale moim zdaniem wśród decydentów nie ma przeświadczenia, że jest to dobry sposób rozwiązania obecnej sytuacji. Rząd ciągle będzie się skupiał na uzyskaniu porozumienia bez konieczności ponownego odwołania się do woli narodu. Obie główne partie obawiają się, że przeprowadzenie drugiego referendum nie zagwarantuje rozwiązania 
problemu, za to wyśle bardzo dwuznaczny przekaz co do jakości demokracji w Zjednoczonym Królestwie. Boją się poważnych konsekwencji, które może wywołać niejednoznaczny wynik referendum i brak zdecydowanej większości za którąś z opcji, a to tylko pogłębi problem.

Wspomniał Pan o demokracji w Wielkiej Brytanii. Czy system polityczny w ogóle przetrwa tę próbę, jaką jest brexit? Od pewnego czasu widzimy wyraźną dekompozycję scen politycznych w wielu państwach UE, a system $w$ Zjednoczonym Królestwie $w$ dalszym ciągu wydaje się stabilny. Czy pozostanie on taki, czy może brexit okaże się silą, która zdemoluje brytyjską scenę polityczną?

Paradoksalnie w obecnej sytuacji i sposobie procedowania sprawy przez parlament możemy zobaczyć, że mamy w Wielkiej Brytanii silne i dobrze działające instytucje. Na wysokości zadania nie stanął jednak system partyjny brexit ujawnił długotrwałą dekompozycję dwóch głównych partii, które dzięki ordynacji wyborczej sztucznie utrzymują zdecydowaną przewagę w parlamencie. Laburzystom i konserwatystom nie zależy więc na zmianie obecnego systemu. W 2011 r. z inicjatywy mniejszościowego koalicjanta konserwatystów, Liberalnych Demokratów, zorganizowano referendum, w którym zaproponowano obywatelom zmianę systemu $\mathrm{z}$ ordynacji większościowej w jednomandatowych okręgach wyborczych na podobną, ale z głosem alternatywnym. Nie spotkało się to jednak z entuzjastycznym przyjęciem głosujących.

Brexit pokazał, że obie główne partie trawią wewnętrzne podziały, i to nie tylko co do wyjścia z UE, ale również w sprawach szeroko pojmowanej filozofii politycznej i kwestii związanych z politykami publicznymi. Proces brexitu prawdopodobnie uświadomi ludziom, że warto zająć się ordynacją wyborczą, by przybliżyć brytyjski system partyjny do rzeczywistych poglądów społeczeństwa, ponieważ w tym momencie dwie główne partie nie są harmonijnymi organizacjami, ale raczej dysfunkcyjnymi koalicjami, które przez obecną ordynację zmuszone są zachowywać spójność, choćby była ona sztuczna.

Czyli brexit może spowodować trwałą zmianę linii podziału na brytyjskiej scenie politycznej w poprzek tego tradycyjnego, między dwiema głównymi partiami?

Myślę, że ten podział już istnieje. Jeszcze przed brexitem mogliśmy zauważyć duże rozbieżności w Partii Pracy, co unaocznił sam Jeremy Corbyn. Widzimy też brak zgodności między parlamentarzystami a dołami partyjnymi, które swego czasu wybrały Corbyna na przewodniczącego, jako polityka 
bardziej lewicowego. Partię Konserwatywną z kolei od kilkudziesięciu lat dzieli kwestia europejska. Na brytyjskiej scenie politycznej jest też jednak wiele innych linii podziału. To nie brexit jest ich przyczyną. Brexit stworzył tylko okazję, by zapoczątkowały one zmiany w systemie politycznym.

Czy referendyzacja polityki w Wielkiej Brytanii nie idzie w poprzek tradycji systemu politycznego, gdzie suwerenem jest jednak parlament, a nie naród? Czy pójście w tym kierunku jest jednorazowym ekscesem, czy raczej mamy do czynienia z nową tendencją w brytyjskiej polityce? Inaczej mówiąc, czy tak jak $w$ innych krajach społeczeństwo Zjednoczonego Królestwa staje się coraz bardziej populistyczne w sposobie realizowania polityki?

Wydaje mi się, że decyzja o przeprowadzeniu referendum wynikała $\mathrm{z}$ refleksji nad pragnieniem obywateli do wypowiedzenia się w sprawie wyjścia z UE. To była kwestia wagi konstytucyjnej - sytuacja, w której ludzie oczekują, by pozwolono im zabrać głos. Referendum pokazało, że mamy bardzo małą większość, która uznaje wynik wyborczy za wystarczające przyzwolenie na całkowite narzucenie swojej woli całkiem sporej mniejszości. Pokazuje to, że populistyczne tendencje są spójne z tym, jak Brytyjczycy rozumieją demokrację. Wydaje się, że istnieje rozdźwięk między tym, czego od parlamentu i rządu oczekują ludzie, a rolą, jaką parlament przyznaje sobie w ramach konstytucyjnej suwerenności. Słychać było wiele głosów niezadowolenia, że parlament nie wykorzystuje do wyjścia z UE po prostu art. 50 Traktatu o Unii Europejskiej, tylko chce odgrywać w całym procesie istotną rolę i przeprowadzić w tej sprawie głosowanie. Podobnie jak kwestia systemu partyjnego brexit pokazał, że nastawienie obywateli do parlamentu, rządu czy instytucji zmieniło się. Nie wykluczałbym więc, że w przyszłości pojawi się oczekiwanie bardziej plebiscytarnego podejścia do demokracji, gdzie większość decydowałaby $w$ istotnych kwestiach. Brexit obnażył jednak poziom braku zaufania i podziałów w społeczeństwie, co może sugerować opinii publicznej, że prowadzenie polityki poprzez referenda nie jest najlepszym pomysłem, bo do takich podziałów prowadzi. Ludzie oczywiście zareagowali na włączenie się parlamentu w proces brexitu, ale pojawia się zaniepokojenie potencjalnymi szkodami, które referenda mogą uczynić poprzez stawianie kwestii politycznych w sposób zero-jedynkowy.

Zajmuje się Pan też szerzej kwestią populizmu. Proszę wyjaśnić, dlaczego i czy rzeczywiście populizm stał się takim game changerem w europejskiej 
polityce i czy można powiedzieć, że populizm pojawil się nagle i zupełnie zmienił sytuację na świecie? Ostatnio czytałem komentowaną przez wielu naukowców książkę Rogera Eatwella i Matthew Goodwina National populism. The revolt against liberal democracy. Stawiają oni tezę, że populizm nie jest niczym nowym, że w pewnym sensie jest stałym elementem demokratycznej polityki. Rodzi się więc pytanie, dlaczego teraz miałoby się coś zasadniczo zmienić, dlaczego populizm coraz częściej postrzegany jest jako element zmieniający reguły gry. W końcu nawet w kampanii wyborczej do PE główna linia podziału przebiega między tymi, którzy reprezentują populizm, i tymi, którzy chcą mu stawić czolo.

Populizm towarzyszy nam od zawsze w tym sensie, że odnosi się do kwestii większości społecznej i woli ludu jako nieodłącznych elementów teorii demokracji. Postrzegany jest różnie przez teoretyków zajmujących się demokracją, ale w każdym demokratycznym systemie politycznym ma możliwość odnoszenia się do idei suwerenności ludu przeciwko elitom politycznym. Istnieje wiele przyczyn wzrostu znaczenia populizmu w ostatniej dekadzie. Niektóre są długoterminowe, np. dekompozycja systemu partyjnego. W wielu krajach fragmentacja sceny politycznej stworzyła idealne warunki do wzrostu sił populistycznych, które wcześniej nie miały tak sprzyjających okoliczności rozwoju. Mamy również do czynienia ze zniechęceniem wyborców wobec partii politycznych. W Europie Środkowej i Wschodniej widzimy np. skłonność do zmian preferencji partyjnych, wobec czego populiści mają dobre warunki do mobilizacji wyborców. Łatwiej przychodzi im krytykowanie elit w najróżniejszych kwestiach niż zaprezentowanie spójnych rozwiązań politycznych. Są teraz w dogodnej pozycji, by czerpać pełnymi garściami z dekompozycji starych podziałów politycznych i partii, które je reprezentują.

Często umyka uwadze, że populiści stali się po prostu bardzo kompetentni - mają większe zdolności mobilizacyjne i lepiej wykorzystują nadarzające się okazje, by przekonać do siebie wyborców szukających partii, na którą mogliby zagłosować. W Polsce był np. Andrzej Lepper, który początkowo mobilizował tłumy, ale zabrakło mu umiejętności i dobrego momentu, by zbudować bardziej znaczący ruch. Po prostu nie był wystarczająco dobrym populistą. Jeżeli jednak zwrócimy uwagę na Nigela Farage'a, to zobaczymy człowieka, który umie komunikować swój sprzeciw wobec elit. Ten wyedukowany w szkołach publicznych makler giełd towarowych i deputowany do Parlamentu Europejskiego potrafi skutecznie przekonać wyborców, że jest głosem sprzeciwu wobec elit. Gdy jednak zajrzymy do jego CV, to okaże się, że mamy do czynienia z typowym przedstawicielem establishmentu. 
To właśnie charakterystyczne dla niego umiejętności komunikacyjne sprawiają, że przyciąga się rozproszonych wyborców, a populizm staje się w ostatnich kilku latach skutecznym sposobem uprawiania polityki.

Czy można więc mówić o nowej generacji populistów w Europie? Jeżeli przyjrzeć się ewolucji populizmu we Włoszech, jeżeli porównać Salviniego i Berlusconiego, to wydaje się, że wydarzyło się w tym czasie coś, co spowodowało, że populizm przeszedł ewolucję. Czy znakiem tego są tylko wspomniane przez Pana większe kompetencje?

Myślę, że chodzi o kompetencje, ale także o stosunek tradycyjnych partii do populizmu. Uderzające jest, że partie głównego nurtu, które dotychczas odcinały się od populistów, są teraz bardziej otwarte na ich pomysły. Kordon sanitarny między nimi został do pewnego stopnia zredukowany, a populizm stał się w pewnym stopniu częścią mainstreamu. Mamy też do czynienia ze zmianami pokoleniowymi. Pojawiają się takie ugrupowania jak Ruch Pięciu Gwiazd we Włoszech, których przesłaniem jest to, że są nowe, że nie mają koneksji ze starymi elitami. Taki populizm nie opiera się na spójnej ideologii politycznej, za to powołuje się na brak skażenia polityką przeszłości. Pozwala to młodym zdolnym politykom populistycznym prezentować swoje poglądy bez oglądania się na stare media. Era mediów społecznościowych daje im szanse, których nie mieliby kilkadziesiąt lat temu, bo nie muszą tworzyć tradycyjnej struktury partyjnej, tradycyjnej organizacji, i nie muszą utrzymywać kontaktów z mediami mainstreamowymi ani dbać o dobre relacje z nimi. Mogą mówić do wyborców bezpośrednio poprzez Facebooka czy Twittera i nie muszą polegać na filtrach mediów tradycyjnych. Jest to jeden z czynników, które wygenerowały potencjał populistów.

A czy można powiedzieć, że istnieje europejski populizm, czy raczej mamy do czynienia w Europie z różnymi populizmami? Jak na tym tle wypada Europa Środkowo-Wschodnia? W jakim stopniu tutejszy populizm jest spójny z populizmem w Europie Zachodniej?

Myślę, że w ciągu ostatniej dekady widzimy ewolucję. W 2008 r. napisałem artykuł naukowy o populizmie, w którym zawarłem m.in. tezę, że jeżeli porównujemy populizm z takimi ideologiami jak socjalizm czy liberalizm, to nie widzimy międzynarodowych organizacji grupujących się wokół wspólnych punktów odniesienia i celów, które spajają partie w różnych krajach. Teraz powoli zaczynamy widzieć próby tworzenia połączeń między 
tymi grupami na poziomie międzynarodowym. Jeszcze w tym roku irlandzki profesor Duncan McDonnell wyda książkę na temat międzynarodowego populizmu. Widzimy, że europejscy populiści wykorzystują instytucje europejskie, by tworzyć między sobą sieci powiązań. Nie mają nawet ze sobą wiele wspólnego, a to, co ich łączy, to tylko kontestacja establishmentu. Nie przeceniałbym jednak ich powiązań. Istnieją oczywiście kwestie łączące np. Viktora Orbána i Jarosława Kaczyńskiego (choćby sposób myślenia o polityce), ale i oni nie do końca sobie ufają. Widzieliśmy też, że Matteo Salvini, który przyjechał ostatnio do Warszawy w celu budowania europejskiej grupy, także nie spotkał się z pozytywnym odbiorem swojej inicjatywy ze strony polskich rządzących. Jest bardzo szeroki zakres potencjalnych kontaktów, jednak najczęściej populiści kończą, rozmawiając tylko o swoich celach. Potencjał do tworzenia szerokich europejskich aliansów (jak np. między socjalistami) jest u populistów niewielki, ponieważ mają oni powierzchowne cele antyestablishmentowe, a gdy przychodzi do konkretów dotyczących poszczególnych polityk, to często albo po prostu ich nie ma, albo nie są spójne z wizjami populistów z innych krajów. Dlatego nie będzie łatwo o stworzenie wspólnego ruchu populistycznego. Jedyną wspólną cechą wszystkich tych środowisk jest to, że odnoszą się do tego samego zjawiska - rosnącego rozczarowania elitami politycznymi, kulturalnymi i kanałami, poprzez które ich idee przekazywane są dalej. Dlatego właśnie populiści przejawiają wrogie nastawienie do tradycyjnych mediów, dzięki którym stare elity zachowują dominację.

\section{Czy doświadczenie komunizmu i transformacji ma jeszcze jakieś zna- czenie dla tworzenia się polityki tego regionu, czy jednak straciło już swoją wagę?}

Trudno sobie wyobrazić, że doświadczenie komunizmu nie zostawiło żadnego śladu. Zarówno w Polsce, jak i w innych państwach regionu widzimy, że podział, który wyłonił się po przemianach, szybko stracił na znaczeniu jako podział między partiami politycznymi i wyborcami. Wyborcy mobilizują się dzisiaj wokół swoich partii politycznych. Jeżeli chodzi konkretnie o kwestię populizmu, to komunizm pozostawił w społeczeństwie głęboką nieufność wobec instytucji władzy - poczucie, że zbytnie zaufanie do elit nie jest dobrym pomysłem. Ten rodzaj myślenia jest coraz bardziej obecny również na Zachodzie, ale to właśnie państwa Europy Środkowej i Wschodniej są w awangardzie szerszych procesów politycznych w Europie. 


\section{Zaczęliśmy od brexitu, więc na i brexicie zakończmy. Jaki będzie jego wpływ na postbrexitową UE, a jaki na postunijną Wielką Brytanię? Jak może to zmienić integrację europejską?}

Proces brexitu potwierdził unijną potrzebę jedności w tej sytuacji. Dla Wielkiej Brytanii ogromnym zaskoczeniem było to, jak uparcie reszta UE wspierała Irlandię. Zjednoczone Królestwo zakładało, że Irlandia będzie niczym zmienna w badaniach naukowych - że można nią będzie manipulować w czasie negocjacji. Szybko jednak okazało się, że UE była w tej sprawie nieprzejednana. Pokazało to też, że Bruksela jest w stanie zadbać o interes całej organizacji w kontrze do współnegocjującego. Stanowiło to też negatywny przykład dla innych, którzy chcieliby podążyć drogą Wielkiej Brytanii.

Jeżeli chodzi o Zjednoczone Królestwo, to gdy już w październiku opuścimy UE - jak by to ujął Churchill - nie będzie to początek końca, ale koniec początku. To będzie moment, gdy zaczną się u nas duże zmiany, począwszy od systemu wyborczego. Po brexicie dojdzie do rozliczeń, co można było zrobić lepiej. Pojawią się też zapewne refleksje nad tym, co w obliczu ostatnich trzech lat trzeba jeszcze w kraju zmienić czy poprawić. Widzimy, że podział w społeczeństwie i wewnątrz partii politycznych jest głęboki. Nie spodziewałbym się jednak natychmiastowych zmian. Podejrzewam, że gdy wrócimy do kwestii brexitu za trzydzieści, czterdzieści lat, będzie on postrzegany jako początek pewnego procesu, a elementy systemu politycznego, które obecnie wydają nam się dane raz na zawsze, zmienią się. W Wielkiej Brytanii zazwyczaj robimy wszystko powoli. Za około pokolenie nie będzie zaskoczeniem, jeżeli okaże się, że mamy zupełnie inną ordynację wyborczą. Obecny system nie jest dostosowany do aktualnych podziałów między partiami politycznymi. Spodziewam się więc początku długiego procesu adaptacji do nowych warunków. 